\title{
Premises for Minority School Leadership in Sweden, Finland and Spain
}

\author{
Pirjo Lahdenperä \\ School of Education, Culture and Communication, Mälardalen University, Eskilstuna, Sweden \\ Email: pirjo.lahdenpera@mdh.se
}

Received 2 July 2014; revised 5 August 2014; accepted 20 August 2014

Copyright (C) 2014 by author and Scientific Research Publishing Inc.

This work is licensed under the Creative Commons Attribution International License (CC BY).

http://creativecommons.org/licenses/by/4.0/

(c) (i) Open Access

\begin{abstract}
This article focuses on the role of principals in minority schools. It attempts, through a case study conducted in three different countries, to determine the conditions that constitute the framework of principal's mission and work. Furthermore it aims to explore what characterizes being a leader of a bicultural and multilingual school. The study is based on interviews with leaders in seven different schools: two in Finland, two in Spain and three in Sweden. One of the main findings indicates that the principal role was directed towards being a "champion", fighting and arguing for the schools uncertain existence. The headmaster had to prioritize promoting the school to various stakeholders as well as establishing it as an institution in the surrounding society. The second finding concerns principals' leadership. Working in a multicultural and multilingual school provides conditions for development of intercultural leadership skills. The principals of these schools have much to contribute to the development of knowledge on management in diversity. Another feature that emerges in the interviews is the principal's high commitment and ability to interact with parents and other stakeholders.
\end{abstract}

\section{Keywords}

Minority Schools, Principal, Intercultural Leadership, Multilingual School, Minority Rights

\section{Introduction}

The language choices and policies for schools serving children with different minority language/s than that of the majority are an issue of great debate in many countries. The views expressed in these debates show contradicting opinions but also reflect dissimilar underlying values. The more valued languages, like English, French and German are often accepted without controversy while acceptance of less valued immigrant languages face a lot of resistance (Hult, 2012; Lainio, 2001; Mtana, 2013). It takes a lot of effort to change the status of a language. There is often a reluctance towards accepting a language as a minority language as it entails an obligation 
for promoting it as an official language (Ammon \& Hellinger, 1992; Hult, 2012).

The right to use and develop minority languages remains to be an important question for minority ethnic groups everywhere. The international convention for civil and political rights stipulates that in those states in which ethnic, religious or linguistic minorities exist, persons belonging to such minorities shall not be denied the right, in community with the other members of their group, to enjoy their own culture, to profess and practice their own religion, or to use their own language (United Nations Human Rights, article 27).

In the Convenant on the Rights of the Child, the development of respect for the child's parents, his or her own cultural identity, language and values, for the national values of the country in which the child is living, the country from which he or she may originate, and for civilizations different from his or her own is emphasized (United Nations Human Rights, CRC, article 29 C).

The article further states that in those states in which ethnic, religious or linguistic minorities or persons of indigenous origin exist, a child belonging to such a minority or who is indigenous shall not be denied the right, in community with other members of his or her group, to enjoy his or her own culture, to profess and practice his or her own religion, or to use his or her own language.

Thus, there are several international agreements, signed by Sweden, ensuring the right to education given in the language of the minority. It is the ratification of these two conventions that, according to the School Inspection (2012: 2), led to the European Council implementing surveillance functions that monitor and guide the Swedish minority language policy. The follow-ups by European Council have resulted in a handful of critical reports from the European Council thus causing investigations and commission work.

The criticisms led to a new law on language in 2009 (Language Act, 2009: 600) and to a new law on minority language in 2010 advocating for the strengthening of the status of minority languages and stated:

$\S 4$ the Language of the Act (2009: 600) states that the public has a special responsibility to protect and promote the national minority languages. The public must also otherwise promote the national minorities to preserve and develop their culture in Sweden. Children's development of a cultural identity and the use of their own minority language should be promoted particularly.

In the year 2000, the European council ratified five languages as official minority languages in Sweden after a long debate in the convention for minority languages in the European council. The languages were Finnish, Meankeli, Sami, Romany, and Yiddish. The Sami, Swedish Finns, Tornedalians, "Romany" and Jews were given official recognition as minority languages (Rodell Olgac, 2006; Ekberg, 2011; School Inspection, 2012).

One of the main goals for instituting the frame convention for protection of national minorities was to develop a plurality of languages in Europe in general and Sweden in particular. In practice, the recognition entails that the minorities in question have the right to communicate and use the language in official context with authorities for example, in childcare and eldercare centers.

The Swedish Independent School Reform in 1992 enabled the establishment of schools for different language groups and culture than that of the Swedish majority resulting in free school choice for these groups. The tradition before 1992 was that these children participated in home language classes (minority or so-called mothers tongues classes) provided by the local schools. The availability of these classes also depended on whether there are an adequate number of minorities in the schools and the willingness of bureaucrats in higher positions $\mathrm{Mu}-$ nicio, 1987; Hyltenstam \& Tuomela, 1996; Tuomela, 2001). The struggle for education in the own languages by the minorities in Sweden has been controversial, and a case example happened in especially in Rinkeby, a multilingual neighborhood in Stockholm where in 1984 the Finnish parents kept their kids at home from school, to demand instruction and use of finish language for the children in school (Jaakkola, 1989). The literature concerning Swedish Finns struggles for language rights, for example, depicting and showing how an invisible group of immigrants have fought their way to an identity as a proud minority ${ }^{1}$ through own minority schools.

It is through the arrangements in school and education system that these minority rights are to be realized (Lainio, 2001; Lainio, Tryggvason, \& Gynne, 2012). Therefore it is of great interest to study the premise for leadership in linguistic minority schools. Inquiries into the leadership in seven minority schools (three in Sweden, two in Finland and two "diasporic"” in Spain) have been conducted to compare the conditions for the

\footnotetext{
${ }^{1}$ Title of a presentation held in the Eskilstuna City hall on the day for Swedish Finns, February 2012.

${ }^{2}$ Diaspora (Greek "embezzlement" in the sense of "Dispersion and scattering”), originally aimed at the Jews forced residence outside their home country, "diasporas", first under the Babylonian captivity and then after the Roman expulsion. But today, the term to refer to many other ethnic groups living abroad, often, but not always, as a result of an involuntary migration (NE, 2012) (last checked 15 May 2014 ). http://sv.wikipedia.org/wiki/Diaspora
} 
schools existence. The purpose of the comparison is to distinguish the national conditions for a minority schools existence in Sweden in comparison with these other countries. One other purpose was to study the challenges and requirements encountered by the minority school leader and to gain insights into how the respondents perceived their work, possibilities and role.

The third objective is to study leadership in minority schools to get answer to question of whether any specific skills or qualities are required in working as a principal in a bicultural minority school.

\section{Study Outline and Methodology}

Semi-structured in depth interviews were used to gain understanding and knowledge into the principals' thoughts of their mission, challenges and conditions school's existing in their schools. The study is inspired by a social constructivist and socio cultural perspective, in which knowledge is considered a set of social constructs rather than an absolute truth.

Reality is created through meanings, values and experiences being ascribed to the phenomena encountered (Foucault, 1972; Rosenau, 1992; Gergen, 1985; Gergen \& Gergen, 1991). The focus was on stories told by the interviewed principals. Stories are, within the social constructivist perspective, regarded as the individual's right to develop self-respect and self-trust (Honneth, 1995; Shotter, 1989; Harré, 1985).

The interviews were conducted during different periods. In Spain two principals were interviewed 2005, in Finland one in 2006 and two in 2011. In Sweden a total of four principals were interviewed; one in 2006, two in 2007 and one in 2012, amounting to totally nine principals. Since many of the interviews were held years ago there is a big chance that the schools have changed their organization. The purpose of my study is not to evaluate the schools organization, on the contrary to gain insights into how the respondents perceived their work, possibilities and role. All interviews took place in the principals' office in their schools. Thus, it gave an opportunity to study the school and its physical particularities that might affect the principals' work while at the same the office provided a familiar environment for respondents to feel free and confident. The deputy principals and representatives for the teachers or for parents participated in the interviews in a few cases.

The researcher first listened to the principals' stories, translated and transcribed the interviews as well as conducted content analysis with interpretations of the interview texts. Since the interviews were semi-structured it increased the role of the researcher's in the construction of the stories. Shotter (1989) and Krippendorff (1991) emphasize the role and responsibility of the scientist throughout the research process. They argue that the researcher plays part in the development of knowledge, requiring awareness and reflections over his or her own part. It is important, according to the constructivist perspective, to relocate the focus of knowledge generation from the individual within the social sphere, to the process of communication between the researcher and his or her surrounding, in which the research is conducted.

\section{Background and Context for the Schools within This Study}

This section will start with a presentation of the context of the schools in the study, the surroundings, history, target population, profile (languages and culture) and management in order to gain a picture of the context in which the principals work. The data encompasses interviews with the principals, school information material such as adverts and writing, literature about the school as well as information from school web pages.

The schools that have been investigated in Finland were the Swedish coeducational school in Tampere and a Finnish-Russian school in the suburbs of Helsinki. The Swedish coeducational school in Tampere is the only Swedish language school in the otherwise Finnish talking city Tampere. The school is private and maintained by the Association for the Swedish Co-educational School in Tampere. The school has been in existence for one hundred years and gets its finance and support from the state, Tampere City as well as other municipalities where some pupils live and Finnish-Swedish funds; whereby the parents don't have to pay. Education is given in Swedish and courses in Finnish and English are given from the $5^{\text {th }}$ grade and onwards. The school functions as a center for the Finnish-Swedish culture in Tampere with several support organizations such as the Swedish women club, the Swedish congregation, the Swedish senior citizens' association etc. The Association for the Swedish Co-educational School in Tampere is in charge for selecting the schools board, direction, principal and teachers. The board constitutes the school's administrative organ in which the principal is the head. The direction is the local steering group consisting of board members, representatives for teachers and other staff as well as representatives for pupils and parents. The principal is also the head of this steering group (Löfman, 1995). 
The Finnish-Russian school has existed over 50 years as a minority language school while the tradition of Russian schools in Helsinki can be traced back to the 1860s. This school was run as a private school until 1977 when the state took responsibility for financing it (Koski \& Vehkanen, 2005). The profile of the Finnish-Russian school is that it provides a functional bilingualism giving the pupils essential skills in both languages. The objective is for all pupils to be well able to understand and talk Russian as well as to take exams given in Finnish. Even Finnish talking parents, without Russian descent, bring their children to the school in order to give them an extra language. The ministry of education, or the state with other words, is in charge for the functioning of the school and for assuring its quality. The school is run by the principal, three assistant principals and a steering group.

Two principals were also interviewed in Spain, one in the Swedish school El Colegio Sueco and one in the Finnish school Escuela Finlandesa in Fuengirola. The Swedish school was initiated over 42 years ago and the Finnish school has recently reached 20 years. Both schools are so called "schools abroad" and have diasporic characteristics as they are located in the Swedish and Finnish "colonies" on the sunny coast in Spain. Both schools follow the curriculum of their respective country and turns to children and juveniles who naturally speak Swedish or Finish at home. Around 30\% of the pupils parents are permanent residents, around 30\% will stay in the country for about five years and the rest of the parents are mobile, hence pupils will both arrive and leave during the semesters. The schools are financed both through state subsidies and from fees collected from the parents.

The objective of the Swedish school is to convey both Swedish and Spanish traditions as well as skills required for a life in Spain. The Finnish school has a clear multilingual profile, the pupils will learn five languages: four of them being mandatory: Finnish, Spanish, English and Swedish. As an extra option there is also the choice between German and Arabic. The Swedish school is run by a private association of parents that selects the steering group consistent of a chairman, four full members and three suppliants. One of the full members is elected by The Swedish National Agency for Education. This is the way in which the Swedish Department for Education, economically supporting the school, gains control and insight. The Finnish school has a supporting organization that selects a steering group consistent of a chairman, a cashier and three other members. The steering group will chose a principal that functions as an executing director at the school.

Four principals were interviewed in Sweden: three for Swedish-Finnish schools and one for the Jewish Hillelskolan. They are all independent schools that are financed through subsidies: school vouchers given by the municipality in which the children live. The schools are not allowed to have charges.

Education in the Swedish-Finnish schools is given both in Finnish and in Swedish. They are politically and religiously impartial following Swedish laws and curriculums. Both schools share the objective of creating a strong Swedish-Finnish identity for the children and to give them knowledge about Swedish, Finnish and Swedish-Finnish culture and language.

The Swedish-Finnish school located in Stockholm is owned by the foundation Stiftelsen Sverigefinska skolan i Stockholm and is run by Sverigefinska skolan i Stockholm Service AB which fully owns the foundation. The school is run like a public company and has a steering group consistent of three members, one representative for the staff and his suppliant, all of them selected by the foundation. The principal is subordinated the foundation.

Sverigefinska skolan i Botkyrka (The Swedish-Finnish school in Botkyrka), in Tumba, was initiated, and is still run, by three enthusiasts: principals and teachers with Swedish-Finnish origins. The school has as objective to give the children a high level of language both in Finnish and Swedish, as well as provide them with a secure identity in the Swedish-Finnish culture with both Swedish and Finnish elements. The school is owned by a public company initiated by the principal and teachers that initiated the school. It is run by a principal and an assistant principal who both also teach in the school during daytime. The principals, together with representatives from different functions, constitute a steering group.

Hillilskolan is an independent Jewish school located in Stockholm. The school, in its previous form, existed as a half-private school run by the Institution for Jewish life in Stockholm until 1954 when it was established in its present form by the Jewish parents' cooperative in 1954. The school is financed through vouchers and funds. The objective of the school is to offer an education that allows the children to live a Jewish life if they prefer. It is, according to the principal, important that the pupils can identify themselves as Jews, to have knowledge about the Jewish traditions and ethical conduct and also to be proud of being Jewish. The school is not dogmatic in the sense that it is possible to be Jewish in several ways. The school is not a religious school but an ethnic school. Education is given in Swedish, Hebrew and English. 
The school's proprietor is a foundation comprising parents that are chosen every two years. The parents association is thereby the employer for the principal and the rest of the staff. The steering group consists of a principal and directors for preschool and after-school centers.

\section{Results}

\subsection{The Schools Conditions for Existence and Proprietorship}

The countries in this study all have different conditions for the minority schools existence, obviously affecting the possibilities and primacy for their governing. The largest differences concern the status of the minority language and the schools proprietorship, the explicit control of the school. Finland is officially a bilingual country with both Finnish and Swedish as mandatory languages: the Finnish-Swedish minority has been constantly present and has a high status as minority language and culture. Even the Finnish-Russian school holds a high status and stable conditions for existence. The Finnish state guarantees the schools survival and quality through the allocation of resources.

Independent schools in Sweden are generally seen as posing a competition to the municipal run school system. Even though independent schools are financed through public funds they are still considered as private and foreign in relationship to "normal" Swedish school organization. The differences between public and the independent schools makes itself noticeable as the staff and management of independent schools are not invited to participate in development of competence or other activities undertaken to improve the school system. Those interviewed in this study feels discriminated and perceive it negatively to be excluded from common gatherings and to lack contact with other principals.

The principal of the Swedish-Finnish school in Botkyrka indicated that in order to build and initiate the school they had to take a personal loan as the school was unable to secure municipal funding. Moreover, she had no contact with Finnish speaking principals in the state controlled schools who may have offered additional support. There appears to be a cleavage between municipal run activities aimed at promoting the Finnish language and similar activities undertaken by independent schools, even though they both share the same objective.

The Jewish school received invitations to participate in municipal organized activities for principals; which could indicate that the government is more positive towards its existence. The schools existence is, on the other hand, under threat and has been forced to heighten surveillance and security systems in the school.

The Swedish and Finnish minority schools in Fuengirola in Spain are financed both by the Swedish and Finish states as well as by school fees. These schools abroad are to be considered as diasporic schools i.e., ensuring or a form of "colony" for emigrants to return to their countries. The principals for both schools noted that the authorities in Fuengirola welcomed them and they felt welcome to participate in activities together with "normal" schools in the area. The contacts with other Spanish principals was not as successful showing some of the challenges in establishing a minorities' schools abroad, requires a lot of time and effort and makes it hard to establish contacts with Spanish principals. The fact that the schools have a high turnover of students who come and go also affects the conditions under which they exist.

\subsection{Proprietorship and Governance}

A steering group runs most of the schools in this study. It is only the Finnish-Russian School that is directly under the control of the state and the ministry of education in Finland. The principals perceived the steering committees both negative and positive, their relationship with a steering group depend on the relationship between the principal and the chairman. The steering group exercised a lot of power and could often ignore the opinion and experience of the principal in important matters. Some schools lacked a clear delegation of authority from the steering group and the principal, giving the chairman of the steering committee a great deal of power.

It could happen that the chairman, being a "layman", lacked knowledge both about policies governing the school and about pedagogical matters. A conflict of interest often occurred, between economical constraints and the requirement to uphold a sufficient quality of education. It was pointed out in the interviews that it could be beneficial to be close to those with power or "shot-callers" to facilitate running of the school. There were neither time nor room for bureaucracy, something that is also confirmed by Lindh (2010) in her master thesis comparing principals in independent and state run schools. The principals in Lindh's study told that the independent schools have better conditions for a successful leadership due to clear guidelines and closeness, characteristics absent in 
schools run by the municipal.

\subsection{Parents as Customers and as a Resource}

All the interviewed principals underlined the importance of building good relations with parents. The parents are regarded as "customers" rather than normal stakeholders. The schools were in one case run by the parents' association whereby the parents functioned as the schools proprietor and employer for the principals, something that did not come without problems. Parents are generally "laymen" in matters concerning the school, led to the school being controlled by non-experts in decision-making roles.

The facts that parents choose to place their children in the given school, drive them to and collect them from the school, and in some cases also pay school fees, all contribute to a necessity for the school to keep continuous contacts with parents and to live up to their expectations. This has proven to be problematic due to the heterogeneity of the parental groups regarding socioeconomic, religious background, educational and lingual, purpose for the visit in the country and ethnical affiliation. The parents also have varying needs for support and contact with the staff and other parents. There can also be disagreements concerning what language to be prioritized and what the focus of school ought to be, as well as the leadership style and cultural affiliation.

All the interviewed principals spoke about the importance of establishing good contacts with parents. The principals were usually blamed when something was wrong which could lead to parents taking their children to other schools. Some of the principals shared the impression that parent were more keen to interfere and give critic and suggestions concerning the direction of the school compared to municipal run schools. Even grandparents were sometimes to be considered as "customers" as they could influence the choice of languages for their grandchildren. It is therefore important to arrange activities in which the whole family could participate and that promote the school. Many of the schools have active parents' associations. These associations gave support to the schools, arranged activities like field trips, sporting days, Christmas markets, festivals, lectures, graduation ceremonies etc. The parents could even take responsibility for reparations and cleaning. The principals could take advantage by giving the parents more room and regarding them as either a resource or as owners of the school.

\subsection{The Principal as a Culture Creating Key Person and Front Figure}

Starting or running a minority school is seldom the idea of a single person. The need for an institution that guarantees the minority's survival is expressed by many, often also requiring enthusiasts who can argue, coordinate and debate for a collective will. Therefore, minority schools are more than just ordinary schools. The schools often function as rallying points for the minority and a culture bearing institution gathering and integrating the minority. The principal was expected to be a key and a front person for the minority and "to be everywhere and in the right place".

Several of the principals pointed out the importance of identifying the school's profile and of carefully balancing between different languages and cultures. It was important to be able to speak different languages and be proficient in various traditions and value systems and to refrain from speaking negatively about other languages and cultural expressions. It was important for schools to collaborate with other institutions such as the church and religious, cultural activities or associations in the creation of the school's identity. The principal was, required to represent the school or even be a representative of his or her country of origin. The principals found it hard to be private due to the role as a front man or figurehead for the school, and many times they even experienced a feeling of being constantly observed. One of the principals used metaphor of sitting on stage to describe the role of the principals in minority schools.

\subsection{The Characteristics of Being the Principal in a Minority School}

It is possible to summarize and interpret answers to the question of whether any specific skills or qualities are required in working as a principal in a bicultural minority school. The analysis draws from a model of intercultural leadership which I have described in the book Intercultural Leadership (Lahdenperä, 2008) to discuss the leadership roles. According to this model, leadership is divided into three different aspects: 1) awareness and understanding, 2) the leader's intentions and actions, and 3) personal skills, attitudes and competencies.

1) Awareness and understanding as a function in the task of minority school principals entails knowing the 
school system of both host and countries of emigration. Awareness of bilingualism issues is central as well as insights into and experiences of being a minority and understanding different socio-economic conditions of the parents represented. Several principals pointed out that the principals are expected to have a passion for bilingualism and to demonstrate their own bilingualism or multilingualism in action. This requirement was specific for the leadership of independent schools. The more uncertain the conditions for the school's are as a bicultural minority school, the more the principal needed to promote bilingualism and minority rights. To understand the importance of traditions and how to build ethnic identity and affiliation was mentioned by most respondents as part of the principal's cultural awareness.

2) Among the intentions, actions and deeds that were mentioned in the interviews I have distinguished between the workload mentioned by principal of independent schools and that common to all the principals interviewed. In a bicultural minority school principals must work double as much and in different languages. Promoting and marketing the school was considered as a skill and action specific for principals in independent minority schools. All mentioned the weight of the principals' promotional activities for their country, language, ethnic minority and the school. It was therefore important to be involved in all cultural events, seen everywhere and build a local, national and international arena for their activities. The principal would constantly work on influencing attitudes and integration as well as establishing to natural interaction with mainstream society while creating solidarity in the minority group.

3) The list of the principal's personal skills, attitudes and skills to work in a bicultural minority school is extensive. Of course the bi- or multilingual educational environment requires a leader with good communication skills in several languages. This list of affective aspects, competencies, skills can be described and summarized by intercultural communicative competence of the leadership (Adler, 2002; Lahdenperä, 2006, 2008, 2009; Trompenaars \& Hampden-Turner, 2004) where the leader can and constantly develops their skills to alternate between different cultural and social contexts and demands.

Experience of living abroad is an added asset, being in a minority position or of being treated specially; when it comes to development of intercultural skills. The principal would show intercultural sensibility by not wondering about anything and not feeling embarrassed neither by guests, different requirements and expectations or conflicts among staff, parents and the ethnic minority. One respondent described these aptitudes as comparable to being the leader of the UN (United Nations), entailing tolerating uncertainty in resolving conflicts. Adler (2002) and Kouzes \& Postner (2007) point out capabilities of tolerance, resolving conflict and alignment of goals and credibility as the important intercultural skills in leadership. To be trustworthy, was also one of the aspects that were mentioned by most of the principals. Having an inner conviction that what you do is important and that it makes a difference, to not give up but to go ahead and continue to believe in the cause, to have an inner compass and honest motives and to have one own goals in line with what the school stands for are all descriptions of different aspects that provide credibility for leadership.

\section{Discussions and Conclusions}

This study on the conditions for linguistic minority schools leadership includes several purposes. The main interest is to study the conditions under which linguistic minority schools in Sweden exist, and the underlying conditions for principals' activities and role.

The studies in three different countries have in addition provided a context and opportunities for comparisons. The study has helped to describe the similarities and differences in conditions for minority schools' existence and the similarities that may appear for leading a bi- or multi-cultural and lingual school.

The main findings of the study indicate that the more uncertain conditions for the minority school existence existed, the more the principal forced to work as a "driving force" to fight or argue for the school's existence was. The principals had to prioritize the promotion of the school and create institutions with different stakeholders of the school. This action was understandable given the initial language of the fight, but in the long run, such a "key person dependency" forms a risk factor for existence and development of the minority school. The important question to be answered is how to comply with the intentions of minority law and the international conventions in ensuring minority language survival.

A review conducted by the School Inspection (2012: 2) concerning mother tongue and bilingual education in national minority languages shows that the municipalities lack sufficient knowledge of, and interest in, the national minorities and the development of their language, leading to a lack of opportunities for many students to 
receive education in minority languages. Furthermore, it is noted that during the more than ten years that have passed since Sweden committed to protect and monitor the national minorities' languages and culture, little progress has been made in practice, as repeatedly criticized by the European Council. Unfortunately, the attitudes and interest, concerning minority rights, held by many municipal representatives and principals, are directly countering the efforts that Sweden committed to do by signing the Convention for minority languages (Schools Inspection, 2012: 2, p. 11).

The question of responsibility for minority schools existence becomes more complicated and important in the light of this review. How is the majority community to organize schooling for children from minority backgrounds and ensure their rights to their language and culture in accordance with minority law without leaving all responsibility to the leaders of minority schools?

The second conclusion from this study concerns principals' intercultural leadership. Being the leader of a minority school requires good collaboration with parents and different stakeholders, flexibility, balance while giving opportunities for intercultural leadership development where awareness, actions and personal skills are interrelated and mutually supportive. The interviews indicate that being the leader of a bi- or multi-cultural organization provides conditions and incentives for the principal to develop their intercultural communicative competence in which respondents emphasize credibility to be central. In order to demonstrate and develop the credibility, the various aspects of leadership —awareness, actions and personal skills—are consistent with each other, which means that what the leader says is to correspond in action.

Working in a multi-cultural and multi-linguistic school provides conditions for an intercultural leadership development in action, which may mean that the principals of these schools have much to contribute to the development of the field of diversity management.

Leadership credibility was highlighted as one of the aspects that principals themselves require their own leadership. An important aspect of the principals' credibility is their own bilingual minority background. Johnson (2006) describes how principals from minority backgrounds have historically functioned as culturally responsive leader, innovators for curriculums and social activists. Sanchez, Thornton, \& Usinger (2009) argue that principals from minority backgrounds are important for students' motivation to learn, performance, aspirations for the future and development of ethnic identity. To study the relationship between students' academic performance and job satisfaction, the importance of the schools management from a minority perspective is an area of research that can contribute to developing the field of knowledge management in diversity.

Research on minority school leadership can be valuable for two reasons. First, it can provide an increased understanding of various premises for leadership. Second and even more important is that, research using minority perspective complements the current and established research on school leadership and can thus contribute to enhancing the understanding of justice and how the rights of minorities are represented and can be realized in practice.

\section{References}

Adler, N. (2002). International Dimensions of Organizational Behavior (5th ed.). Ohio: Thomson South-Western.

Ammon, U., \& Hellinger, M. (Eds.) (1992). The Status Change of Languages. Berlin \& New York: Walter de Gruyter. http://dx.doi.org/10.1515/9783110851625

Ekberg, L. (2011). The National Minority Languages in Sweden-Their Status in Legislation and in Practice. In G. Stickel (Ed.), National, Regional and Minority Lanquages in Europa (pp. 87-93). Frankfurt am Main: Peter Lang Internationaler Verlag der Wissenschaften.

Foucault, M. (1972). The Archaeology of Knowledge and the Discourse on Language. New York: Pantheon.

Gergen, K., \& Gergen, M. (1991). Toward Reflexive Methodologies. In F. Steier (Ed.), Research and Reflexivity (pp. 76-96). London: Sage Publications.

Gergen, K. J. (1985). The Social Constructionist Movement in Modern Psychology. American Psychologist, 40, 266-275. http://dx.doi.org/10.1037/0003-066X.40.3.266

Harré, R. (1985). Situational Rhetoric and Self-Presentation. In J. P. Forgas (Ed.), Language and Social Situations (pp. 175-186). New York: Springer Verlag. http://dx.doi.org/10.1007/978-1-4612-5074-6_10

Honneth, A. (1995). The Struggle for Recognition: The Moral Grammar of Social Conflicts. London: Polity Press.

Hult, F. (2012). English as a Transcultural Language in Swedish Policy and Practice. TESOL Quarterly, 46, 30-57.

Hyltenstam, K., \& Tuomela, V. (1996). Hemspråksundervisningen. In K. Hyltenstam (Ed.), Tvåspråkighet med förhinder? 
Invandrar-och minoritetsundervisning i Sverige (pp. 9-109). Lund: Studentlitteratur.

Jaakkola, M. (1989). Den etniska mobiliseringen av sverigefinnarna. Stockholm: Ceifo, University of Stockholm.

Johnson, L. (2006). Making Her Community a Better Place to Live: Culturally Responsive Urban School Leadership in Historical Context. Leadership and Policy in Schools, 5, 19-36. http://dx.doi.org/10.1080/15700760500484019

Koski, P., \& Vehkanen, L. (2005). Muutoksen peili. Suomalais-venäläisen koulun historia 1955-2005. Suomalais-venaläinen koulu, Helsinki: Yliopistopaino.

Kouzes, J. M., \& Postner, B. Z. (2007). The Leadership Challenge (4th ed.). San Francisco, CA: Jossey-Bass.

Krippendorff, K. (1991). Reconstructing (Some) Communication Research Methods. In F. Steier (Ed.), Research and Reflexivity, Inquiries in Social Constructions (pp. 115-143). London: Sage Publications.

Lahdenperä, P. (2006). Intercultural Leadership in School Environments. Reports, Huddinge: Södertörn University College, 627. http://sh.diva-portal.org/smash/record.jsf?pid=diva2:16341\&searchId=1

Lahdenperä, P. (2008). Interkulturellt ledarskap-förändring i mångfald. Lund: Studentlitteratur.

Lahdenperä, P. (2009). How to Develop an Intercultural School: Experiences from Sweden. In M. T. Talib, J. Loima, H. Paavola, \& S. Patrikainen (Eds.), Dialogs on Diversity and Global Education (pp. 107-122). Frankfurt am Main: Peter Lang Internationaler Verlag der Wissenschaften.

Lainio, J. (2001). The Protection and Rejection of Minority and Majority Languages in the Swedish School Systems. In S. Boyd, \& L. Huss (Eds.), Managing Multilingualism in a European Nation-State: Challengers for Sweden (pp. 32-50). Clevedon, Buffalo, Toronto \& Sydney: Multilingual Matters Ltd.

Lainio, J., Tryggvason, M. T., \& Gynne, A. (2012). Flerspråkiga sverigefinska ungdomar på den nordiska arbetsmarknadenmöjligheter och förväntningar. Slutrapport från BilMinNord-projektet. In Litteratur och språk nr 8 (2012), Västerås: Mälardalen University.

Language Act (2009: 600). Ministry of Culture, Government Offices of Sweden. http://www.government.se/sb/d/8317/a/138133

Lindh, M. (2010). En studie i rektors syn på ledarskap i fristående skolor. Självständigt arbete i ledarskap. Magisterprogrammet med inriktning mot ledarskap, Akademin för Samhälls-och Beteendevetenskap, Västerås: Mälardalens högskola.

Löfman, A. (1995). Hundra år av gemenskap 1895-1995. Jyväskylä: Gummerus Kirjapaino, Oy i Finland.

Mtana, N. (2013). Tanzanian Primary School Learners Investing in English. Ph.D. Thesis, Stockholm: Stockholm University.

Municio, I. (1987). Från lag till bruk. Hemspråksreformens genomförande. Centrum för invandrarforskning, Statsvetenskapliga institutionen, Stockholm: Stockholms universitet, $\mathrm{Nr} 31$.

Nationalencyklopedin (NE) (2012). (last checked 15 May 2014) http://sv.wikipedia.org/wiki/Diaspora

Rodell Olgaç, C. (2006). Den romska minoriteten i majoritetssamhällets skola: Från hot till möjlighet. Ph.D. Thesis, Studies in Educational Sciences 85, Stockholm: HLS Förlag.

Rosenau, P. M. (1992). Post-Modernism and the Social Sciences. Princeton, NJ: Princeton University Press.

Sanchez, J. E., Thornton, B., \& Usinger, J. (2009). Increasing the Ranks of Minority Principals. Western Michigan University, Educational Leadership: Developing School Leaders, 67, 96-103.

School Inspection (2012). I marginalen. En granskning av modersmålsundervisning och tvåspråkigundervisning i de nationella minoritetsspråken. Kvalitetsgranskning, Rapport 2012:2 Skolinspektionen.

Shotter, J. (1989). Social Accountability and the Social Construction of “You”. In J. Shotter, \& K. Gerger (Eds.), Text of Identity (pp. 133-151). London: Sage Publications.

Trompenaars, F., \& Hampden-Turner, C. (2004). Managing People across Cultures. Chichester: Capstone Publishing Ltd.

Tuomela, V. (2001). Modersmålsundervisningen-en forskningsöversikt. Bilaga till rapporten Flera språk-fler möjligheter. Utveckling av modersmålsstöd och modersmålsundervisning-ett regeringsuppdrag, 2002, Dnr: 2001-2751.

United Nations Human Rights. Convention on the Rights of the Child: Adopted and Opened for Signature, Ratification and Accession by General Assembly Resolution 44/25 of 20 November 1989, Article 29 C. http://childrensrights.ie/childrens-rights-ireland/un-convention-rights-child

United Nations Human Rights. International Covenant on Civil and Political Rights, article 27. http://www.ohchr.org/en/professionalinterest/pages/ccpr.aspx 
Scientific Research Publishing (SCIRP) is one of the largest Open Access journal publishers. It is currently publishing more than 200 open access, online, peer-reviewed journals covering a wide range of academic disciplines. SCIRP serves the worldwide academic communities and contributes to the progress and application of science with its publication.

Other selected journals from SCIRP are listed as below. Submit your manuscript to us via either submit@scirp.org or Online Submission Portal.
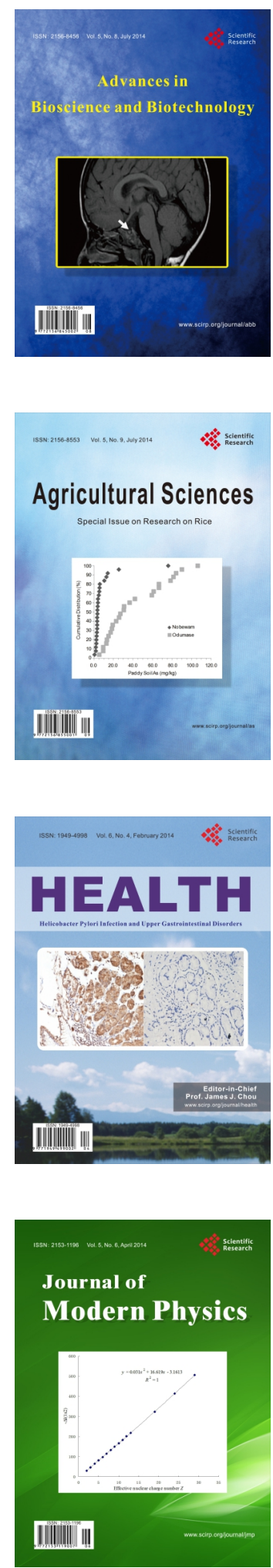
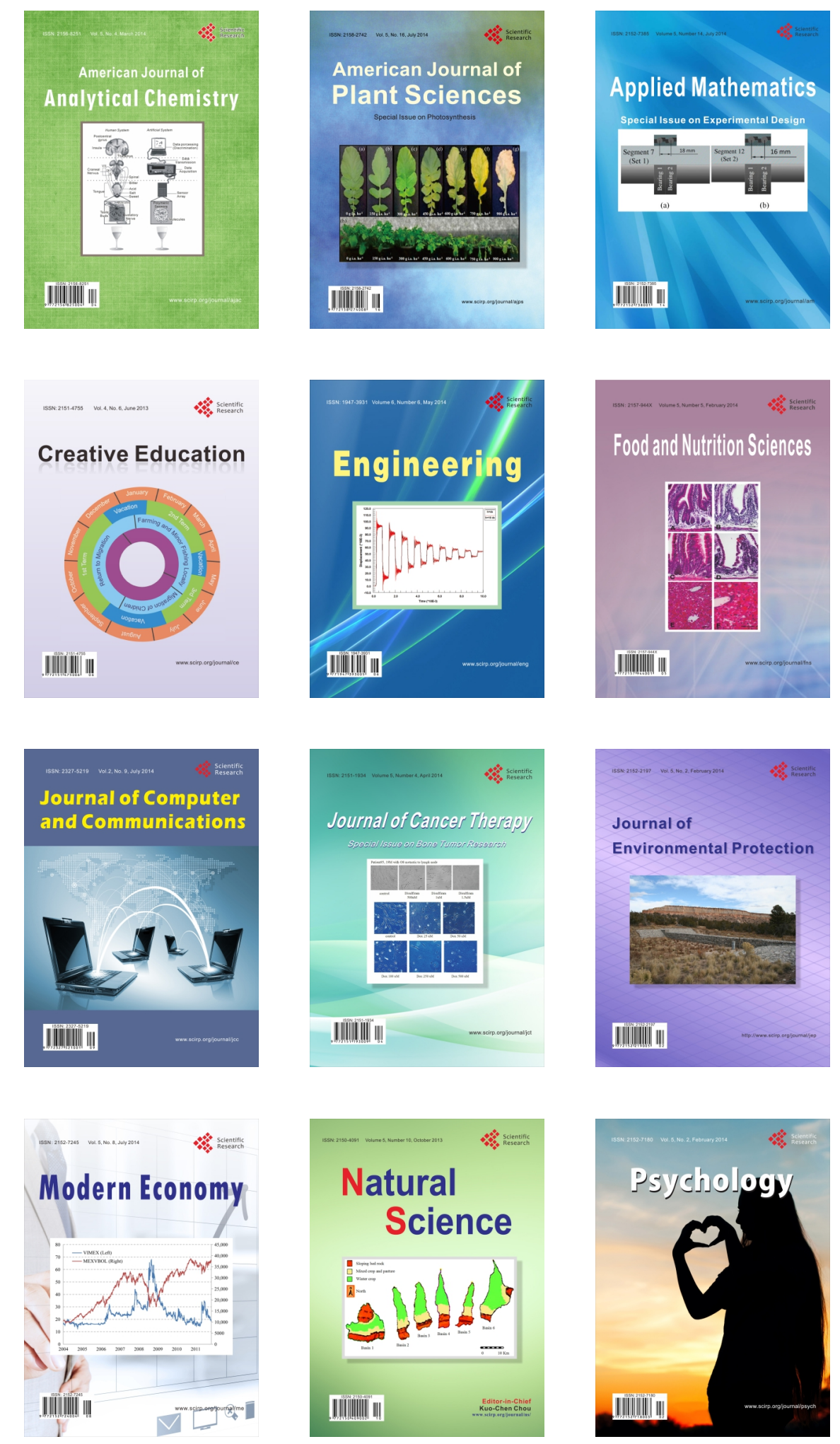